\title{
PILIHAN MATERIAL BANGUNAN PADA CANDI
}

\author{
Bambang Perkasa Alam \\ Program Studi Arsitektur, Universitas Indraprasta PGRI
}

\begin{abstract}
Abstrak. Bangunan candi sering kali ditemukan dalam keadaan rusak. Namun di balik sisa reruntuhan bangunan tersebut, masih terlihat jejak proses pembangunannya. Material yang digunakan untuk membangun candi, yang paling sering dijumpai adalah batu andesit dan batu bata merah. Material batu bata merah biasanya dipergunakan pada candi yang ditemukan di areal persawahan dan jauh dari gunung berapi, sedangkan yang menggunakan batu andesit biasanya di dekat sungai, tidak jauh dari gunung berapi. Artikel ini mendiskusikan perbedaan penggunaan material pembangun candi tersebut serta faktor yang memengaruhinya. Studi ini menggunakan metode kualitatif. Pengambilan data dilakukan melalui studi kepustakaan, di mana sumber informasi utamanya adalah buku, laporan, artikel ilmiah, serta film semi dokumenter tentang ekskavasi candi di beberapa tempat di Indonesia. Hasil pembahasan menunjukkan bahwa pilihan material pembangun candi tidak terkait secara langsung dengan periode pembangunannya, melainkan dengan ketersediaan bahan yang dipengaruhi oleh lokasi pembangunan, serta terkait dengan tingkat kesakralan bangunan yang hendak didirikan.
\end{abstract}

Kata kunci: batu andesit, batu bata, candi, material

\begin{abstract}
Temple buildings were often found in a state of disrepair. However, behind the ruins of the building, there were still traces of the construction process. The materials used to build temples, which were most often encountered were andesite and red bricks. Red brick material was usually used in temples found in rice fields and far from volcanoes, while those that used andesite stones were usually near rivers, not far from volcanoes. This article discusses the differences in the use of the temple building materials and the factors that influence them. This study used qualitative methods. Data were collected through literature studies, where the main sources of information were books, reports, scientific articles, and semi-documentary films about the excavation of temples in several places in Indonesia. The results of the discussion showed that the choice of temple building materials was not directly related to the construction period, but with the availability of materials which is influenced by the construction location, as well as the sacred level of the building to be erected.
\end{abstract}

Keywords: andesite stone, red bricks, temple, material

Correspondence author: Bambang Perkasa Alam, perkasaalam.bambang@gmail.com, Jakarta, Indonesia 


\section{PENDAHULUAN}

Indonesia memiliki banyak candi yang tersebar di hampir seluruh Pulau Jawa dan Bali, serta sebagian Sumatera dan Kalimantan (Soekmono, 1995). Secara umum, pada masa kerajaan-kerajaan Hindu-Budha di Indonesia, masyarakat menggunakan candi sebagai tempat pemujaan dewa dan dewi (Soekmono, 1973: 81). Akan tetapi, terdapat perbedaan fungsi candi pada agama Hindu dan Budha. Bagi agama Hindu, candi lebih merupakan penanda kekuasaan, sedangkan agama Budha menempatkan candi sebagai tempat peribadatan. Selain tempat ibadah, beberapa bangunan yang tidak dilengkapi simbol-simbol keagamaan juga tetap dinamakan candi, termasuk bangunanbangunan yang dipergunakan sebagai pintu gapura, tempat pemandian, istana, penanda kekuasaan, ataupun sebagai makam para raja.

Arsitektur bangunan candi dirancang dengan sentuhan seni yang tinggi. Kualitas estetis ornamen ukiran maupun seni pahat yang terdapat pada candi mengisyaratkan bahwa pada eranya, kerajaan-kerajaan Hindu dan Budha memiliki arsitek-arsitek dengan keahlian yang mumpuni. Keberadaan relief yang biasa menghiasi bangunan candi juga menunjukkan bahwa pada masa itu keindahan seni telah mendapat perhatian dan menjadi bagian penting dari kehidupan masyarakat, khususnya di lingkungan kerajaan.

Padanan untuk istilah candi dalam bahasa Inggris, 'temple,' berasal dari bahasa Latin 'templum,' yakni bangunan yang dikhususkan untuk ritual, kegiatan spiritual dan/atau keagamaan, seperti kegiatan doa dan pengorbanan (Soekmono, 1973). Jika dikembalikan kepada pengertian dasarnya dalam bahasa Indonesia, maka istilah candi dapat mencakup pula semua bangunan bersejarah Hindu-Budha yang terdapat di seluruh dunia, bukan hanya di Indonesia Dumarcay. Candi memiliki rupa dan fungsi yang sangat beragam, dan dianggap sebagai tempat bersemayamnya satu atau beberapa dewa. Secara historis, keberadaan candi di Indonesia tidak terlepas dari sejarah dan perkembangan agama Hindu-Budha di Jawa sejak abad ke-7 sampai abad ke-14, serta di daerah Sumatera dan Kalimantan (Supriatna, 2006).

Bukan hanya rupa dan fungsinya, material pembuat candi pun bermacammacam, antara lain batu granit, batu bata, dan batu kapur. Keragaman material inilah yang menjadi pokok diskusi dalam artikel ini. Apakah yang menjadi penyebab keragaman pemilihan material tersebut? Apa pula alasan penggunaan suatu material pada candi-candi tertentu?

\section{METODE PENELITIAN}

Penelitian ini menggunakan metode kualitatif. Pengumpulan data dilakukan dengan teknik kajian kepustakaan. Sumber data yang digunakan antara lain artikel jurnal ilmiah, majalah, buku, maupun artikel-artikel dari sumber daring di internet. Selain itu, data yang dibutuhkan juga diambil dari sumber berupa film tentang penggalian arkeologis di situs candi. 


\section{HASIL DAN PEMBAHASAN}

\section{Candi dan Material Pembangunnya}

Bangunan candi sering kali dihubungkan dengan monumen sebagai tempat pendharmaan untuk memuliakan raja yang telah wafat. Namun demikian, candi bukanlah makam, melainkan bangunan kuil (Soekmono, 1973: 241). Selain merujuk pada bangunan tempat ibadah agama Hindu-Budha, kata candi juga dipergunakan untuk menyebut bangunan istana, pemandian/petirtaan, gapura, dan sebagainya (Maryanto, 2007: 8). Menurut Yudoseputro (1993: 118), bangunan candi digunakan sebagai bangunan suci, namun di India sendiri, bangunan candi tidak digunakan sebagai tempat ibadah. Di India, bangunan kuil untuk menyelenggarakan upacara agama Hindu disebut vimanna (rumah dewa) atau ratha (kendaraan dewa), sedangkan untuk ibadah agama Budha disebut stupa. Sebutan candi di Indonesia merujuk pada bangunan dengan bermacam-macam fungsi, yaitu kuil Hindu, stupa dan wihara Budha, pemandian, pintu gerbang (gapura), ataupun candi sebagai bale kambang, pusat pengajaran agama, tempat menyimpan abu jenazah raja, tempat pemujaan atau bersemayam dewa. Walaupun fungsinya bermacam-macam (Dumarcay) candi diartikan juga sebagai replika rumah tinggal para dewa yang sebenarnya, yaitu Gunung Mahameru (Supriatna, 2006).

Mengingat fungsinya yang tidak dapat dilepaskan dari kegiatan keagamaan Hindu dan Buddha pada masa lalu, sejarah pembangunan candi juga tak dapat dilepaskan dari sejarah kerajaan-kerajaan Hindu-Buddha di Indonesia sejak abad ke-5 sampai dengan abad ke-14. Bangunan candi banyak mendapat pengaruh dari India, misalnya dalam aspek teknik bangunan, gaya arsitektur, dan ornamen atau hiasan. Walaupun demikian, arsitektur candi di Indonesia mempunyai karakter tersendiri, baik dalam penggunaan bahan, teknik konstruksi, maupun corak dekorasinya. Hal ini karena pengaruh kebudayaan dan kondisi alam setempat juga sangat kuat. Dinding candi biasanya dihiasi relief tentang ajaran atau cerita tertentu.

Aturan pembuatan bangunan gapura atau candi yang dipegang teguh oleh para seniman bangunan di India dimuat dalam sejumlah kitab keagamaan, antara lain Manasara dan Sipa Prakasa. Para seniman candi pada masa itu percaya bahwa ketentuanketentuan di dalam kitab-kitab keagamaan tersebut bersifat suci dan magis. Bangunan yang dibuat secara benar dan indah mempunyai arti tersendiri, baik bagi pembuatnya maupun penguasa yang memerintahkan pembangunannya, dan akan mendatangkan kesejahteraan dan kebahagiaan masyarakat. Oleh karena itu, ketika akan membuat gapura, persiapan dan perencanaan yang matang harus dilakukan, baik secara keagamaan maupun teknis. Salah satu bagian penting dalam perencanaan teknis adalah membuat sketsa yang benar agar dapat dihasilkan bangunan seperti yang diharapkan. Sketsa ini harus didasarkan pada aturan dan persyaratan tertentu terkait bentuk, ukuran, maupun posisi dan tata letaknya. Jika dalam proses pendirian bangunan terjadi penyimpangan atau keluar dari ketentuan-ketentuan di dalam kitab keagamaan, maka akan berakibat pada kesengsaraan besar bagi pembuat maupun masyarakat sekitarnya. Namun demikian, meski ketentuan-ketentuan dalam kitab keagamaan tidak dapat diubah dengan semaunya, suatu kebudayaan, termasuk seni bangunan, akan selalu dipengaruhi oleh keadaan alam dan budaya setempat, serta pengaruh waktu. 
Pada awal proses pembangunan candi, seseorang yang menjadi pelaksana pembangunan (Yajamana), bersama para pekerjanya (Silpin), harus menghubungi Maha Brahma. Selanjutnya, berdasarkan arahan Maha Brahma, mereka akan mencari lokasi yang tepat untuk membangun candi. Lokasi pembangunan candi yang paling baik adalah dekat sungai, terutama pertemuan dua aliran sungai yang disebut sebagai tempuran. Pada umumnya, candi terbuat dari batu hitam yang disebut batu candi, yang sebenarnya adalah batu andesit. Andesit adalah suatu jenis batuan beku vulkanik ekstrusif. Batuan jenis ini sering dipergunakan pada bangunan-bangunan megalitik, candi dan piramida. Batuan ini terbentuk dari magma dengan temperatur antara 900$1.100^{\circ}$ Celcius. Mineral-mineral yang terkandung di dalamnya bersifat mikroskopis, antara lain silika $\left(\mathrm{SiO}_{2}\right)$ sejumlah kisaran 52-63\%, kuarsa sejumlah kisaran 20\%, biotite, basalt, feltise, plagiocase feldspar, pyroxene (clinopyroxene dan orthopyroxene), serta hornblende dengan persentase sangat kecil (Hannigan).

Batu andesit dapat dikatakan bernilai seni tinggi karena memiliki komposisi dan tekstur spesifik yang dapat dipahat. Batuan ini biasanya ditemukan pada lingkungan subduksi tektonik di daerah-daerah dengan aktivitas vulkanik yang tinggi, seperti di Majalengka, Cirebon, dan Tulung Agung. Motif batu andesit pada umumnya ada dua jenis, yaitu polos dan berbintik. Batu andesit polos terbentuk akibat sedimentasi, mempunyai tingkat kekerasan (density) sangat tinggi, dan porositas rendah, sehingga teksturnya halus sekali. Pada umumnya jenis batu ini berwarna gelap atau hitam. Oleh karena sifatnya yang keras dan porositasnya kecil, batu andesit tidak mudah kotor. Beberapa candi yang terletak di daerah Dieng maupun sekitaran Magelang seperti candi Borobudur dan Prambanan, menggunakan material batu andesit.

Material lain yang juga kerap digunakan untuk membangun candi adalah batu bata, yang terbuat dari tanah liat yang dicetak, kemudian dibakar. Batu ini dapat menyerap panas dengan baik. Bata merah sudah sangat umum digunakan sebagai material bangunan di Indonesia, dari zaman dulu hingga saat ini. Tanah yang digunakan untuk pembuatan bata bukanlah sembarang tanah. Tanah tersebut harus yang agak liat sehingga bisa menyatu saat proses pencetakan.

\section{Faktor yang Melatarbelakangi Pilihan Material Candi}

Bata yang dipakai di Indonesia adalah jenis bata bakar, yang baru hadir pada permulaan awal sejarah Nusantara bersamaan dengan masuknya budaya Hindu-Budha dari India ke Nusantara. Sebagian pendapat menyebutkan, penggunaan batu bata lebih muda daripada material batu andesit. Pendapat ini berpangkal dari kategorisasi seni bangun candi ke dalam dua langgam (gaya seni), sebagaimana dikemukakan oleh Soekmono (1973: 81), yakni candi berlanggam Jawa Tengahan yang dibangun pada periode antara abad ke-7 sampai abad ke-11 Masehi, dan candi berlanggam Jawa Timuran yang dibangun pada periode antara abad ke-13 sampai abar ke-16 Masehi. Di antara keduanya, terdapat langgam transisi yang dibangun antara abad ke-12 sampai abad ke-13 Masehi (Soekmono, 1973: 81).

Pada kategorisasi ini, candi berlanggam seni Jawa Timuran dinyatakan sebagai berbahan bata. Padahal, bahan material yang digunakan, apakah bata atau batu, tidaklah terkait langsung dengan langgam seni ataupun lapis masa. Pilihan material ini lebih dipengaruhi oleh ketersediaan jenis material di lingkungan sekitar tempat pembangunan candi, dan kesakralan bangunan yang bersangkutan. Pada dasarnya, 
sebagai bangunan sakral, material yang digunakan dalam pembangunan candi harus kuat dan tahan lama, seperti batu.

Batu kali (andesit), batu kapur, atau batu padas keras, yang dalam bahasa Jawa disebut curing, tidak selalu tersedia dalam jumlah cukup di lingkungan sekitar pembangunan. Oleh karena itu, penggunaan material lain tidak dapat dihindari, antara lain batu bata. Batu bata yang digunakan biasanya adalah bata berukuran besar dan tebal. Kualitas pembakaran yang matang akan membuat batu bata tersebut tahan usia. Bangunan candi-candi yang menggunakan material batu bata umumnya berada jauh dari areal gunung berapi. Pada candi-candi ini, material yang kemudian kerap digunakan, di samping batu bata, adalah kayu keras untuk bagian dinding dan atap. Kalaupun batu dipakai, umumnya hanya untuk bagian tertentu. Misalnya, sebagai media pahat bagi ragam hias candi, batu pengunci (key stone), arca dewa, dan sebagainya. Untuk bangunan-bangunan profan, digunakan batu bata untuk komponen pondasi, gapura, pagar, dan sebagainya, sedangkan pada bagian lain digunakan bahanbahan yang tidak tahan usia, seperti kayu, bambu, atau ilalang. Akibatnya, bagian bangunan-bangunan ini kini tidak lagi tersisa jejaknya.

Terdapat sejumlah bukti yang menunjukkan bahwa penggunaan material batu bata pada candi juga berusia tua, yakni sekitar abad ke-6 sampai ke-10 Masehi. Periode ini relatif sezaman dengan Kerajaan Tarumanegara. Dari periode ini ditemukan jejak arsitektur berlatar keagamaan Budha Mahayana yang berada di situs Batuhaya, Kabupaten Krawang, Jawa Barat. Di situs tersebut ditemukan hampir dua puluh reruntuhan bangunan batu bata, yang tersebar pada areal persawahan seluas $5 \mathrm{~km}^{2}$. Situs lain yang bisa dikatakan sezaman, yang terbuat dari batu bata adalah kompleks percandian Hindu pada situs Cibuaya di Pedes, Krawang. Selain itu, ditemukan juga reruntuhan candi dari batu bata di Kampung Sukamaju, Desa Sukajaya, Kecamatan Pamarican, Kabupaten Ciamis, yang dinamai Candi Binangun. Jejak bangunan candi berbahan batu bata didapati pula di sekitar candi Borobudur, yang berupa candi-candi bukur (candi kecil), dari sekitar abad ke-8 Masehi. Salah satu di antaranya adalah Candi Banon (Attewell \& Farmer, 1976).

\section{SIMPULAN}

Tidak semua candi menggunakan batu andesit sebagai bahan pembangunnya. Batu bata juga digunakan sebagai material pembangun pada beberapa candi, khususnya di daerah Jawa Timur. Penggunaan Batu andesit banyak digunakan pada candi yang dibangun di daerah yang dekat dengan pegunungan, sehingga tersedia material batu andesit yang melimpah, terutama di daerah aliran sungai. Adapun batu bata banyak digunakan pada candi yang letaknya jauh dari gunung berapi. Pada daerah berdirinya candi-candi ini umumnya berlimpah material pembentuk batu bata, yaitu tanah liat. Penggunaan kedua material secara bersamaan pun bisa terjadi, yakni untuk fungsi bangunan berbeda, di mana candi menggunakan batu andesit, sedangkan bangunan penunjang menggunakan batu bata. Dari hasil pembahasan diperoleh pemahaman bahwa pilihan penggunaan material pembangun, apakah batu andesit atau batu bata, tidak berhubungan secara langsung dengan periodesasi pembangunan candi, melainkan dengan ketersediaan bahan dan kesakralan bangunan. 


\section{DAFTAR PUSTAKA}

Attewell, P. B., \& Farmer, T. W. Principles of Engineering Geology. John Wiley \& Sons, Inc., 1976.

Dumarçay, Jacques. Candi Sewu: dan Arsitektur Bangunan Agama Budha di Jawa Tengah. Kepustakaan Populer Gramedia, 2007.

Hannigan, Tim. A Brief History of Indonesia: Sultans, Spices, and Tsunamis, the Incredible Story of Southeast Asia's Largest Nation. TUTTLE Publishing, 2015.

Maryanto, Daniel A. Seri Fakta dan Rahasia di Balik Candi: Mengenal Candi. Citra Aji Parama, 2007.

Soekmono, R. The Javanese Candi, Function and Meaning. E. J. Brill, 1995.

---. Pengantar Sejarah Kebudayaan Indonesia 2. Kanisius, 1973.

Supriatna, Nana. Sejarah. PT Grafindo Media Pratama, 2006.

Yudoseputro, Wiyoso. Pengantar Wawasan Seni Budaya. Departemen Pendidikan dan Kebudayaan, 1993. 